\title{
Precast Prestressed Concrete Truss-Girder for Roof Applications
}

\author{
Peter Samir ${ }^{1}$ and George Morcous ${ }^{2}$ \\ ${ }^{1}$ Omaha Public Power District, 444 South 16th Street Mall, Omaha, NE 68102, USA \\ ${ }^{2}$ University of Nebraska-Lincoln, 1110 South 67th Street, Omaha, NE 68182, USA \\ Correspondence should be addressed to George Morcous; gmorcous2@unl.edu
}

Received 24 July 2014; Revised 4 November 2014; Accepted 19 November 2014; Published 14 December 2014

Academic Editor: Domenico Bruno

Copyright (C) 2014 P. Samir and G. Morcous. This is an open access article distributed under the Creative Commons Attribution License, which permits unrestricted use, distribution, and reproduction in any medium, provided the original work is properly cited.

\begin{abstract}
Steel trusses are the most popular system for supporting long-span roofs in commercial buildings, such as warehouses and aircraft hangars. There are several advantages of steel trusses, such as lightweight, ease of handling and erection, and geometric flexibility. However, they have some drawbacks, such as high material and maintenance cost, and low fire resistance. In this paper, a precast concrete truss is proposed as an alternative to steel trusses for spans up to $48 \mathrm{~m}(160 \mathrm{ft})$ without intermediate supports. The proposed design is easy to produce and has lower construction and maintenance costs than steel trusses. The truss consists of two segments that are formed using standard bridge girder forms with block-outs in the web which result in having diagonals and vertical members and reduces girder weight. The two segments are then connected using a wet joint and post-tensioned longitudinally to form a crowned truss. The proposed design optimizes the truss-girder member locations, cross-sections, and material use. A $9 \mathrm{~m}$ (30 ft) long truss specimen is constructed using self-consolidated concrete to investigate the constructability and structural capacity of the proposed design. A finite element analysis of the specimen is conducted to investigate stresses at truss diagonals, verticals, and connections. Testing results indicate the production and structural efficiency of the developed system.
\end{abstract}

\section{Introduction}

Structural steel is typically and widely used for long-span roof applications, such as warehouses, storage facilities, and airplanes hangars. Design considerations for roof support system include cost-effectiveness, speed of construction, structural capacity, aesthetic appearance, fire resistance, and structural integrity during construction and in service. Using structural steel has been the only option when it comes to long-span roofs due to ease of handling and erection, geometric flexibility, and lightweight. Concrete has not been a competitive alternative for roof applications due to the heavy weight and construction complexity of concrete components, which results in being less cost effective than steel. Despite the advantages of structural steel roof systems, they have the following disadvantages: low fire resistance, being prone to corrosion, high maintenance cost, long lag period in steel orders, and increasing prices of steel. Most of these disadvantages can be addressed by using precast concrete components as they have excellent fire and corrosion resistance, low production and maintenance cost, and short order period.
However, existing precast concrete roof systems are either limited to $30 \mathrm{~m}(100 \mathrm{ft})$ span, such as hollow cores and double tees [1], or heavy and lack aesthetic appearance, such as deep inverted tees and I-girders. Therefore, the main objective of this research project is to develop a precast/prestressed concrete truss system for roof applications with spans from $30 \mathrm{~m}$ to $48 \mathrm{~m}$ (100 ft to $160 \mathrm{ft}$ ) which achieves the following goals: lightweight, aesthetic appealing, cost effectiveness, and fabrication using existing techniques and production practices.

Precast concrete trusses were first used in 1962 for the U.S. Science Pavilion (now Pavilion Science Center) in Seattle, WA. These trusses were nonstructural trusses and were made for architectural purposes [2]. In 1976, Rock Island Parking structure was built using Vierendeel trusses made of horizontal and vertical members with rigid joints and no diagonal members. The trusses used were almost $3.6 \mathrm{~m}(12 \mathrm{ft})$ deep and had a clear span of $9.7 \mathrm{~m}(32 \mathrm{ft})$, which resulted in a span-to-depth ratio of 2.7. All top chord, bottom chord, and vertical members had a cross-section of $405 \mathrm{~mm} \times 560 \mathrm{~mm}$ 
(16 in. $\times 22$ in.) [3]. Vertical members were posttensioned to resist tension forces.

Precast/prestressed concrete trusses were introduced in 1978 in the ACI Journal article titled "Prestressed Concrete Trusses" [4]. The article discussed two prototypes: prototypeI that had a clear span of $6.1 \mathrm{~m}(20.3 \mathrm{ft})$ and a depth of $0.6 \mathrm{~m}$ ( $2 \mathrm{ft})$, for a span-to-depth ratio of 10 and prototype-II that had a clear span of $18.4 \mathrm{~m}(60.8 \mathrm{ft})$ and a depth of $2.6 \mathrm{~m}(8.5 \mathrm{ft})$ for a span-to-depth ratio of 7 . The first prototype had only diagonal members with no verticals; however, the second prototype had diagonal members and two verticals near the center of the trusses. All top, bottom, and diagonal members were prestressed. However, the prestressing in the diagonals was only $35 \%$ of the jacking stresses due to the large friction losses occurring at the hold-down devices. The authors stated that the members cracked at an early stage of loading due to the fact that the diagonals were not adequately prestressed. The authors also stated that using concrete trusses would lower the price to almost half what it would cost if steel alternative was used. In 2007, a new system of concrete trusses was developed for a multilevel condominium building built in Minneapolis, MN, using the so-called "ER-Post." The ERPost is system invented by M. DeSutter of Erickson Roed \& Associates to provide a column-free space for condominiums [5]. DeSutter was able to pretension Vierendeel trusses that were $4.1 \mathrm{~m}$ (13.5 ft) deep and of spanning $20.3 \mathrm{~m}(67.33 \mathrm{ft})$ for a span-to-depth ratio of 5 [6].

In 2010, a precast concrete truss-girder was designed to support the roof of a coal storage facility in Sharjah, United Arab Emirates (UAE). Designed by e.Construct USA, LLC, the $1.5 \mathrm{~m}(5 \mathrm{ft})$ deep truss had a span of $50 \mathrm{~m}(165 \mathrm{ft})$ without intermediate supports, which resulted in a spanto-depth ratio of 33 . The truss consisted of two precast truss segments; each segment is $25 \mathrm{~m}$ ( $82.5 \mathrm{ft})$ long. The two segments were connected using posttensioning tendons and cast-in-place concrete joint. Several trusses were erected at $10 \mathrm{~m}(30 \mathrm{ft})$ spacing to create the crowned roof. Figure 1 shows the built trusses and temporary support used during erection at the midspan to support the two truss segments until posttensioning was applied and the cast-in-place concrete joint was hardened.

According to e.Construct USA, LLC, the use of precast concrete truss system, along with Z-shape steel purlins and metal roof decking resulted in about $25 \%$ saving in the building cost compared to the original design using structural steel. This is a significant saving that motivated the authors to further investigate precast concrete truss systems to optimize their designs, improve their constructability, and accommodate production practices in the United States. Several enhancements, which will be discussed in Section 2, have resulted in cost and weight reductions, and, consequently, the potential of using precast concrete trusses in long-span roof applications.

\section{Development of the Proposed System}

The precast concrete truss system proposed in this study is an evolution of the Sharjah truss-girder system presented earlier. The main enhancements that have been proposed to address

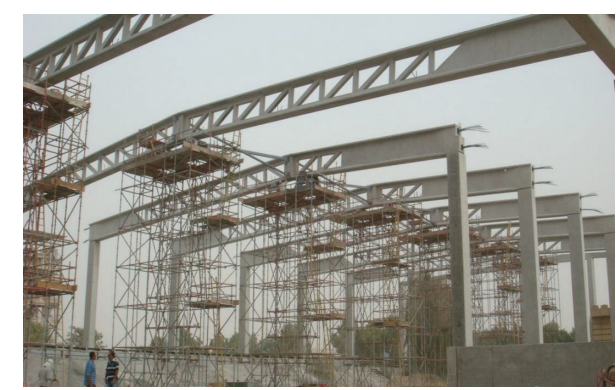

Figure 1: The temporary supports used before posttensioning (courtesy of e.Construct, LLC).

design, fabrication, and construction issues include (1) changing the orientation of diagonals to be compression members made of conventionally reinforced concrete; (2) using high strength steel threaded rods for tension members (verticals) to eliminate cracking; (3) using readily available forms of typical precast/prestressed concrete bridge I-girders, such as AASHTO and bulb tee, with modular block-outs to simplify production; (4) using high performance self-consolidating concrete (SCC) to ensure the quality, efficiency, and economy of truss fabrication; and (5) placing posttensioning ducts in the bottom flange to eliminate the need for thicker webs at girder ends. To present these enhancements, an example building has been chosen to design the proposed truss-girder system. Figure 2 shows the plan and elevation views of the example building layout, respectively. The span of the trussgirders is $48 \mathrm{~m}(160 \mathrm{ft})$ with a $5 \%$ slope (crowned truss). The

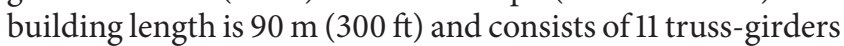
that have $9 \mathrm{~m}(30 \mathrm{ft})$ spacing.

2.1. System Analysis and Design. The proposed system is designed in accordance with the ASCE 7-10 Standard of Minimum Design Loads for Buildings and Other Structures [7]. Vertical loads that are applied to the roof are dead load $(D)$, (roof) live load $\left(L_{r}\right)$, and snow load $(S)$. Lateral loads, such as wind and earthquake loads, are considered to be resisted by shear walls or column bracing systems similar to those used in a typical warehouse structure and, therefore, will not be presented in this paper. A snow design load of $1.44 \mathrm{kN} / \mathrm{m}^{2}$ (30 psf) in addition to $0.72 \mathrm{kN} / \mathrm{m}^{2}$ (15 psf), for mechanical, electrical, and pluming (MEP) loads and metal roof decking, is used for load calculations. To analyze the proposed truss-girder system, the AASHTO-PCI bulb tee girder (BT-72) is chosen for the truss-girder section as an example of a readily available section to most precast bridge producers. The structural analysis program SAP2000 is used to model the proposed truss-girder using frame elements with point loads applied at purlin locations. Vertical members have moment releases at both ends to carry axial load only. Analysis results under factored loads show that maximum axial forces in the top flange, bottom flange, and vertical and diagonal members are 7,486 kN (1,683 kip compression), $7,553 \mathrm{kN}$ (1,698 kip tension), $605 \mathrm{kN}$ (136 kip tension), and $1,192 \mathrm{kN}$ (268 kip compression), respectively. For shipping, handling, and erection phases, analysis results indicate that 

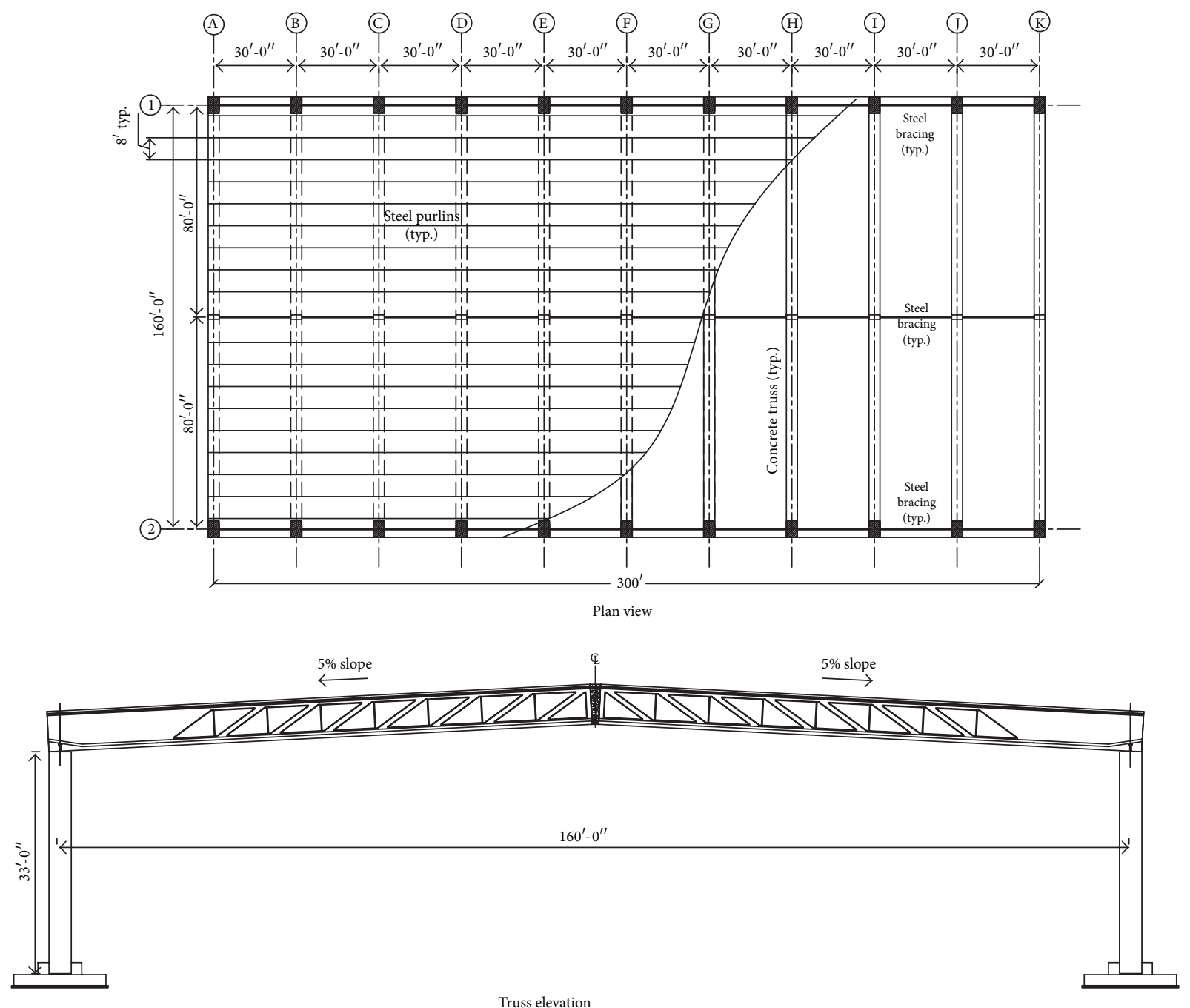

Figure 2: Plan and elevation views of the example building $(1 \mathrm{ft}=0.302 \mathrm{~m})$.

forces in the top and bottom flanges are not critical. However, a tension force of $271 \mathrm{kN}$ (61 kip) in the diagonal members and a compression force of $129 \mathrm{kN}$ (29 kip) in the vertical members are developed under factored construction loads. Midspan deflection under service live load is $160 \mathrm{~mm}$ (6.3 in.), which represents $\mathrm{L} / 305$.

The proposed truss system is designed using the strut and tie method according to Appendix A of the ACI 31811 code [8]. Diagonal members are designed as reinforced concrete struts, while the vertical members are designed as steel ties. The diagonal members have a specified concrete compressive strength of $55 \mathrm{MPa}(8,000 \mathrm{psi})$ and $200 \mathrm{~mm} \times$ $200 \mathrm{~mm}$ ( 8 in. $\times 8$ in.) square section reinforced with 4 number 19 (\#6) Grade 420 (60) (reinforcement ratio of 2.75\%) to resist the tension force experienced during construction when the truss is being temporarily supported at the midspan prior to casting the wet joint and posttensioning. Also, number 10 (\#3) Grade 420 (60) steel square ties are used as transverse reinforcement at $200 \mathrm{~mm}$ (8 in.) spacing. The vertical members are made of $38 \mathrm{~mm}$ (1.5 in.) diameter threaded rods with yield strength of $724 \mathrm{MPa}(105 \mathrm{ksi})$ and ultimate strength of $862 \mathrm{MPa}$ (125 ksi) [9]. Despite the low tensile force carried by the vertical members near the midspan, the same threaded rods are used in all verticals to simplify fabrication and resist the compression force induced during construction without buckling [10].

The bottom and top flanges of the truss are also designed using strut and tie method. The compression strut (top flange) has a specified concrete compressive strength of $55 \mathrm{MPa}$ $(8,000$ psi) and is reinforced with 4 number 13 (\#4) Grade 420 (60). The tension tie (bottom flange) has two posttensioning ducts with 12-15.3 mm (0.6 in.) diameter Grade 1860 (270) low relaxation strands. In addition, $10-15.3 \mathrm{~mm}$ (0.6 in.) diameter Grade 1860 (270) low relaxation pretensioned strands are used for truss transportation and handling. Figures 3 and 4 show concrete dimensions and reinforcing details of the proposed truss-girder system. Comparing the design of the proposed system with the one implemented in the Sharjah 


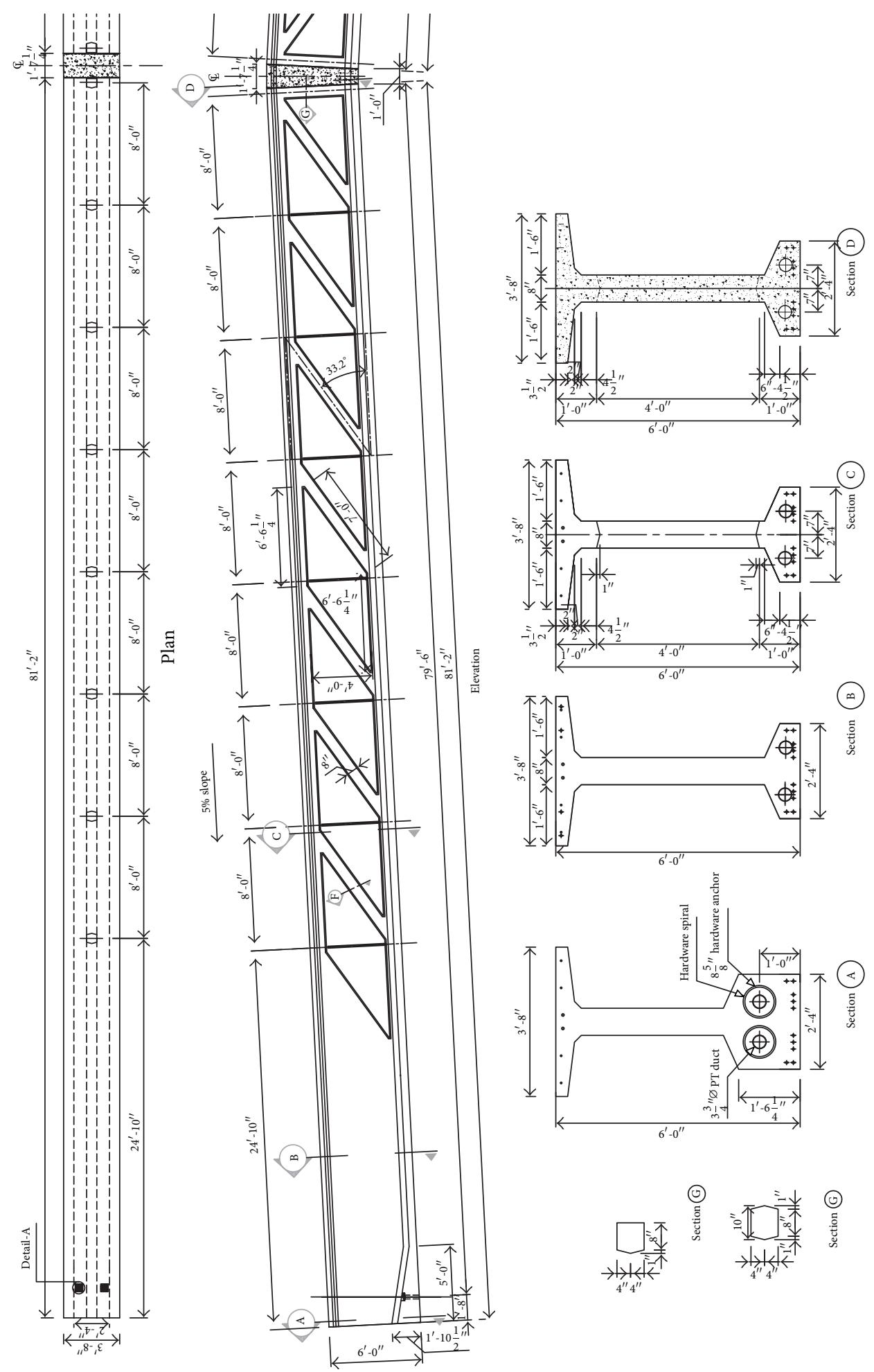

Figure 3: Concrete truss dimensions $(1 \mathrm{ft}=0.302 \mathrm{~m}, 1 \mathrm{in} .=25.4 \mathrm{~mm})$.

coal storage facility, presented in Figure 1, indicates that the proposed system is approximately $23 \%$ lighter in weight in addition to being more economical to produce due to the use of standard I-girder forms, conventional reinforcing details, and self-consolidated concrete.
2.2. Construction Sequence. The proposed construction sequence of the developed truss-girder system is as follows.

(1) Truss-girders are fabricated in the precast plant in two segments for each truss and transported to the construction site. 


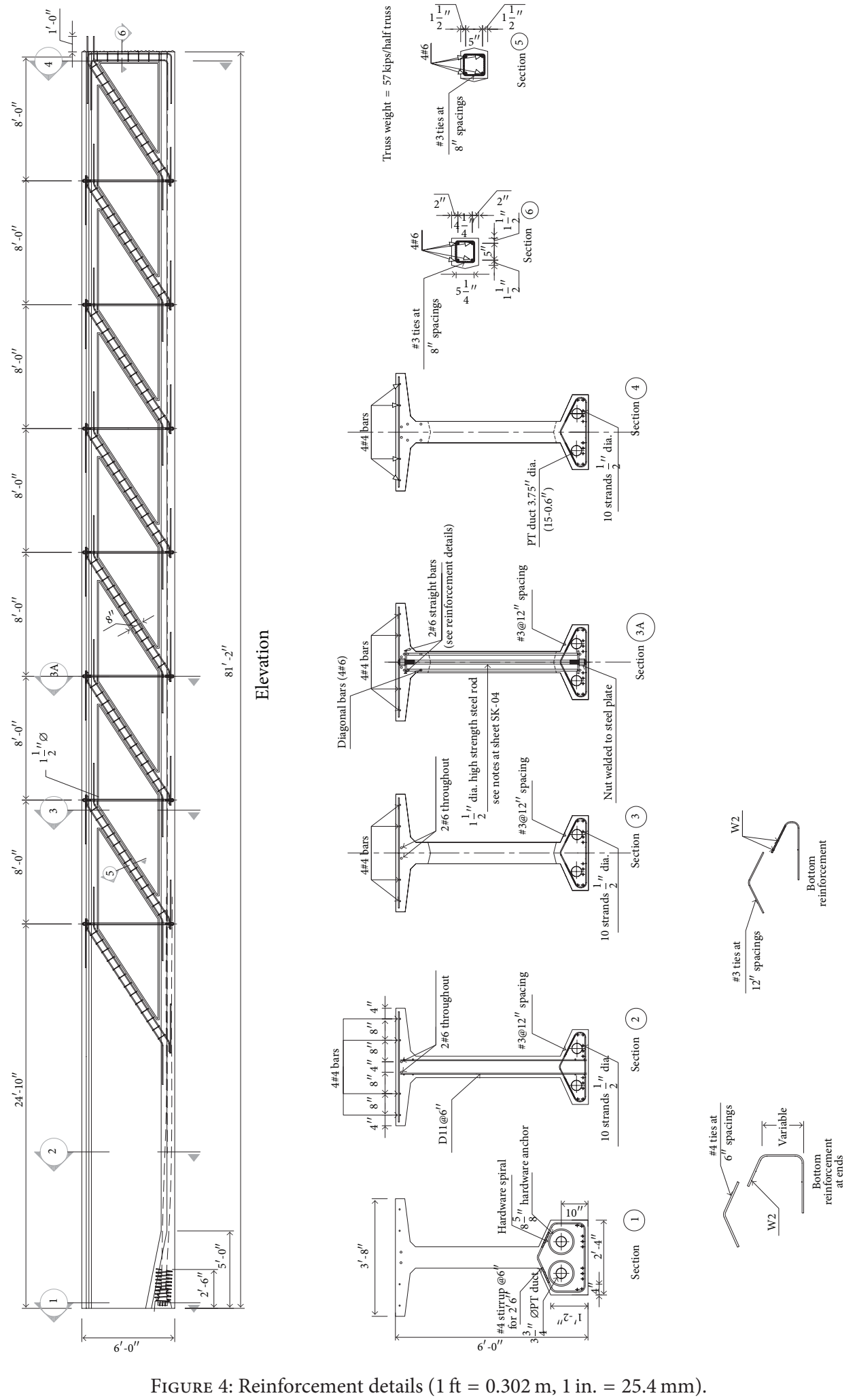



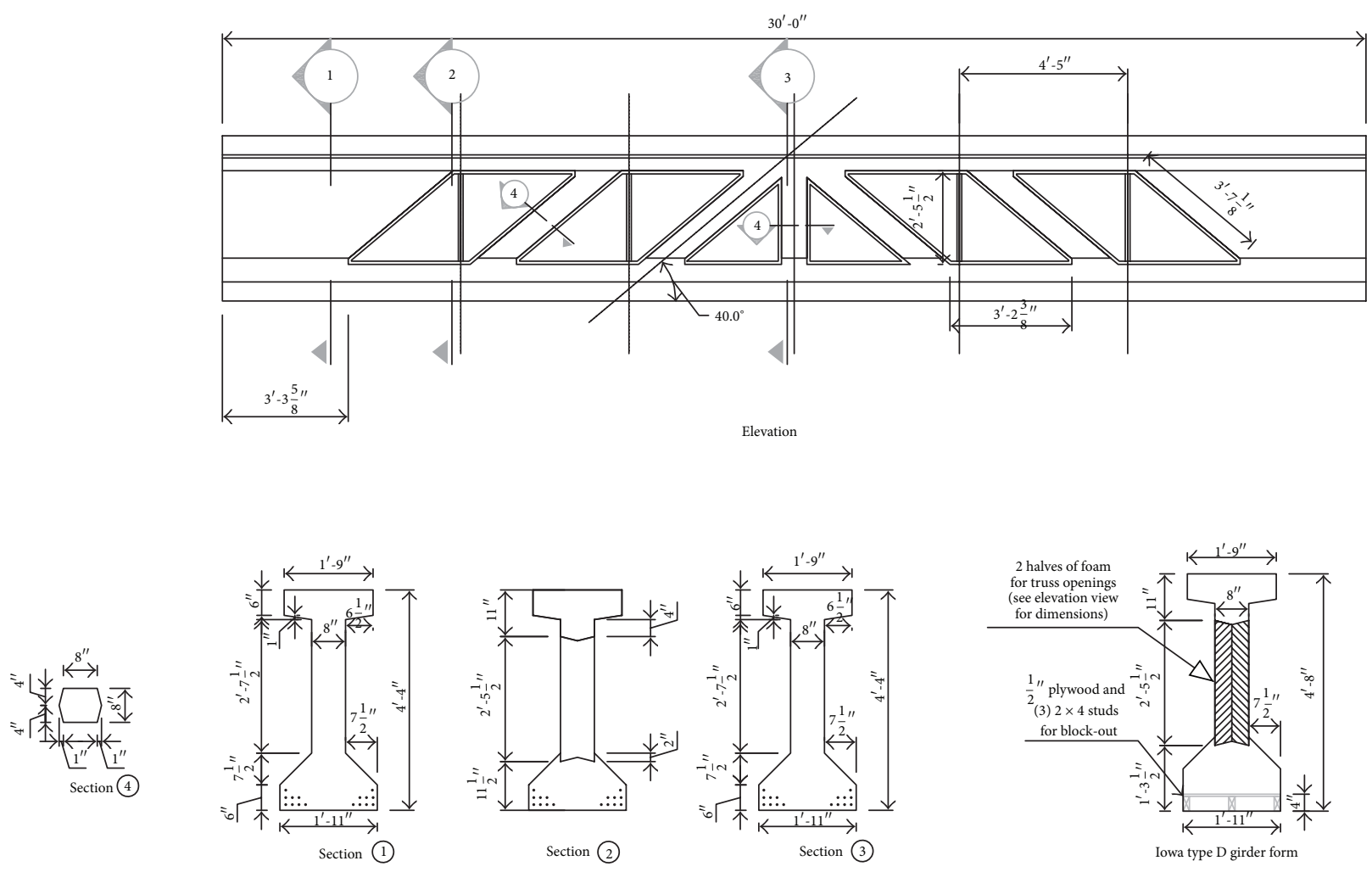

Figure 5: Dimensions of the concrete truss specimen $(1 \mathrm{ft}=0.302 \mathrm{~m}, 1 \mathrm{in} .=25.4 \mathrm{~mm})$.

(2) Each segment is erected on one column at one end and on temporary supports at the other end.

(3) Roof purlins and bracings are installed to stabilize the truss-girders.

(4) Couplers are used to connect posttensioning ducts, and posttensioning strands are threaded through ducts.

(5) Joints between truss segments are formed, reinforced, and cast in place using SCC with similar properties to those of the truss concrete.

(6) Posttensioning is applied after joint concrete achieves adequate strength, and posttensioning ducts are grouted.

(7) Temporary supports are removed and roof decking is installed.

(8) Fire-proofing and corrosion resistance agents are applied to steel elements if needed.

\section{Experimental Investigation}

3.1. Specimen Description. The purpose of the experimental investigation is to evaluate the constructability and structural performance of the proposed truss-girder system. A full-size truss could not be fabricated and tested due to space and

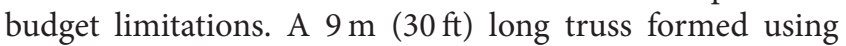
Iowa type $\mathrm{D}$ bridge I-girder forms provided by Coreslab
Structures Inc., Omaha, NE, was used instead. The crosssection dimensions of Iowa type D I-girder are very close to those of AASHTO type IV bridge girder. The forms are $9 \mathrm{~m}$ (30 ft) long, and 1,420 mm (56 in.) high. However, to reduce the weight of the specimen, a $100 \mathrm{~mm}$ (4 in.) blockout was made at the bottom of the form to have a total depth of $1,320 \mathrm{~mm}$ (52 in.) and two foam panels, $100 \mathrm{~mm}$ (4 in.) thick each, were used to form for each truss opening. Figure 5 shows the dimensions of the concrete truss specimen at different sections.

3.2. Specimen Analysis and Design. Two-dimensional (2D) frame analysis and three-dimensional (3D) finite element analysis (FEA) were carried out to determine member forces and deformations of the specimen. Comparing analysis results of each method, as shown in Table 1, indicates that the simple 2D frame analysis results in conservative and relatively accurate estimates of forces and deflections compared to the more elaborate FEA. The loads used in this analysis include, weight of the specimen, prestressing force, and midspan concentrated load which achieve forces in the diagonal and vertical members of the specimen similar to those in the fullsize truss-girder system designed in the previous section. It should be noted that diagonal members of the specimen had a $40^{\circ}$ angle with the bottom flange in order to achieve the same ratio between diagonal and vertical forces as in the full-size truss system presented earlier.

The analysis of the specimen indicated that a midspan point load of $1,779 \mathrm{kN}$ (400 kip) will result in the forces 
TABLE 1: Comparing analysis results using 2D frame model and 3D FE model.

\begin{tabular}{lcc}
\hline Analysis method & $\begin{array}{c}\text { 2D frame } \\
\text { analysis }\end{array}$ & $\begin{array}{c}\text { Finite element } \\
\text { analysis }\end{array}$ \\
\hline $\begin{array}{l}\text { Max. compression in } \\
\text { diagonals }(\mathrm{kN})\end{array}$ & 1,246 & 1,125 \\
$\begin{array}{l}\text { Max. tension in } \\
\text { verticals }(\mathrm{kN})\end{array}$ & 574 & 534 \\
$\begin{array}{l}\text { Cracking load }(\mathrm{kN}) \\
\begin{array}{l}\text { Corresponding } \\
\text { deflection }(\mathrm{mm})\end{array}\end{array}$ & 1,478 & 1,335 \\
\hline
\end{tabular}

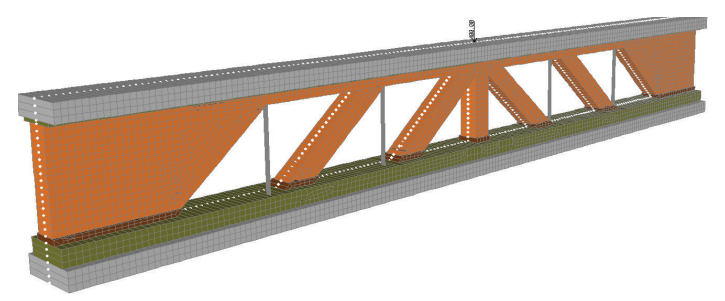

FIgURE 6: The FE model used to analyze truss connections.

that are slightly higher than the design factored forces in diagonal and vertical members. The initial design of the specimen required $16-15.3 \mathrm{~mm}$ (0.6 in.) diameter Grade 1860 (270) strands. However, due to the unavailability of this size of strands at the structural laboratory, $12-17.8 \mathrm{~mm}$ (0.7 in.) diameter Grade 1860 (270) strands were used instead to achieve the same prestressing force. Also, the analysis indicated that the cracking load is $1,468 \mathrm{kN}$ (330 kip) using the cracking stress limit at the bottom fibers and the corresponding deflection is $25 \mathrm{~mm}$ ( $1 \mathrm{in}$.). Strand jacking stress was assumed to be $0.75 f_{\text {pu }}$ and total prestress losses were assumed to be $20 \%$ of the jacking stress. The developed FE model of the specimen, shown in Figure 6, consists of a simplified crosssection (i.e., rectangles), 8-node solid elements for concrete, and frame elements for threaded rods. This model was used to conduct elastoplastic analysis using specified material properties to determine stresses and deformations under different loading levels. Figure 7 shows the stress contours on concrete elements under ultimate load. This figure indicates that the connection between diagonal web and the bottom flange had very high tensile stresses, which are expected to cause premature cracking at those locations.

The specimen was designed similar to the full-size truss with one exception; top and bottom flanges were overdesigned to ensure that the failure occurs at the verticals, diagonals, or connections. The $12-17.8 \mathrm{~mm}$ ( $0.7 \mathrm{in}$.) diameter strands were provided to achieve a flexural capacity of $4,371 \mathrm{kN} \cdot \mathrm{m}(3,224 \mathrm{kip} \cdot \mathrm{ft})$, which is about $10 \%$ more than the applied moment. Also, the top flange was reinforced with 2 number $25(\# 8)$ bars as compression reinforcement to increase the capacity of the top flange. Figure 8 shows the elevation, cross-sections, and reinforcement details of the specimen.

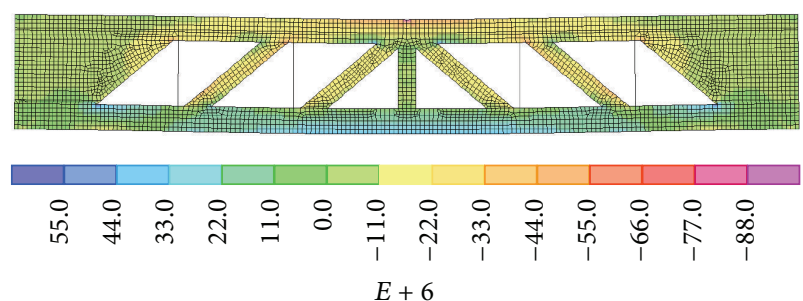

Figure 7: Stresses in the truss specimen under ultimate load at midspan $\left(\mathrm{N} / \mathrm{m}^{2}\right)$.

3.3. Specimen Fabrication. Fabrication of the $9 \mathrm{~m}(30-\mathrm{ft})$ long specimen was done at the structural lab of the Peter Kiewit Institute (PKI) in Omaha, NE, in five major steps: (1) preparing forms and placing prestressing strands, (2) cutting foam block-outs and gluing them to the steel forms, (3) assembling diagonal and vertical reinforcement and installing them between the foam block-outs, (4) casting selfconsolidating concrete into the forms; and (5) stripping the forms and releasing the strands.

The prestressing strands were tensioned to $3,176 \mathrm{kN}$ (714 kip) ( 0.75 of the ultimate stress of $1860 \mathrm{MPa}(270 \mathrm{ksi})$ ). Foam block-outs were used to form the truss openings. The $100 \mathrm{~mm}$ (4 in.) thick foam panels were cut into diamond shapes and glued to form the $200 \mathrm{~mm}$ ( 8 in.) thick blockouts. Square grooves that are $19 \mathrm{~mm} \times 19 \mathrm{~mm}(0.75 \mathrm{in} . \times$ 0.75 in.) were removed from the edges of the foam panels to accommodate the vertical threaded rods as shown in Figure 9. To facilitate the stripping of the foam from the concrete web, plastic sheets were wrapped around the edges of the foam. All the foam block-outs were glued on the steel form after marking their locations on the form sides. Bottom flange and top flange reinforcement were simple to install. The challenge was assembling and installing the diagonal and vertical reinforcement, which were 4 number 19 (\#6) bars and number $10(\# 3)$ ties spaced at $200 \mathrm{~mm}$ (8 in.) along the member and $38 \mathrm{~mm}$ (1.5 in.) diameter threaded rods. The rods were anchored at the top and bottom flange using $200 \mathrm{~mm} \times 200 \mathrm{~mm} \times 13 \mathrm{~m}(8$ in. $\times 8$ in. $\times 0.5$ in. $)$ Grade 350 (50) steel plates and structural nuts. Each plate is welded to two diagonal bars and 2 number 19 (\#6) straight anchor bars. Initially, it was planned to have the reinforcements for each diagonal preassembled and then connected to the threaded rods after being installed in the form. The main problem of this plan is that it requires very tight tolerances in reinforcement dimensions and bent locations in addition to the difficulty of handling a very heavy assembly of reinforcement that is not very stiff. Some diagonal bars were slightly shorter than others and do not have exactly the same bend diameter or location. To address these challenges, diagonal bars and anchor bars were cut to have only $225 \mathrm{~mm}$ (9 in.) of embedment $\left(12 \mathrm{~d}_{\mathrm{b}}\right)$ and transverse ties were kept loose to allow the bars to move relative to each other; then they are tied after all reinforcement is in place to simplify the fabrication process as shown in Figure 9. Four $100 \times 100-$ MW20 × MW20 $(4 \times 4-$ W2.9 $\times$ W2.9 $)$ WWR were placed at the solid part at each end of the truss for shear reinforcements. 

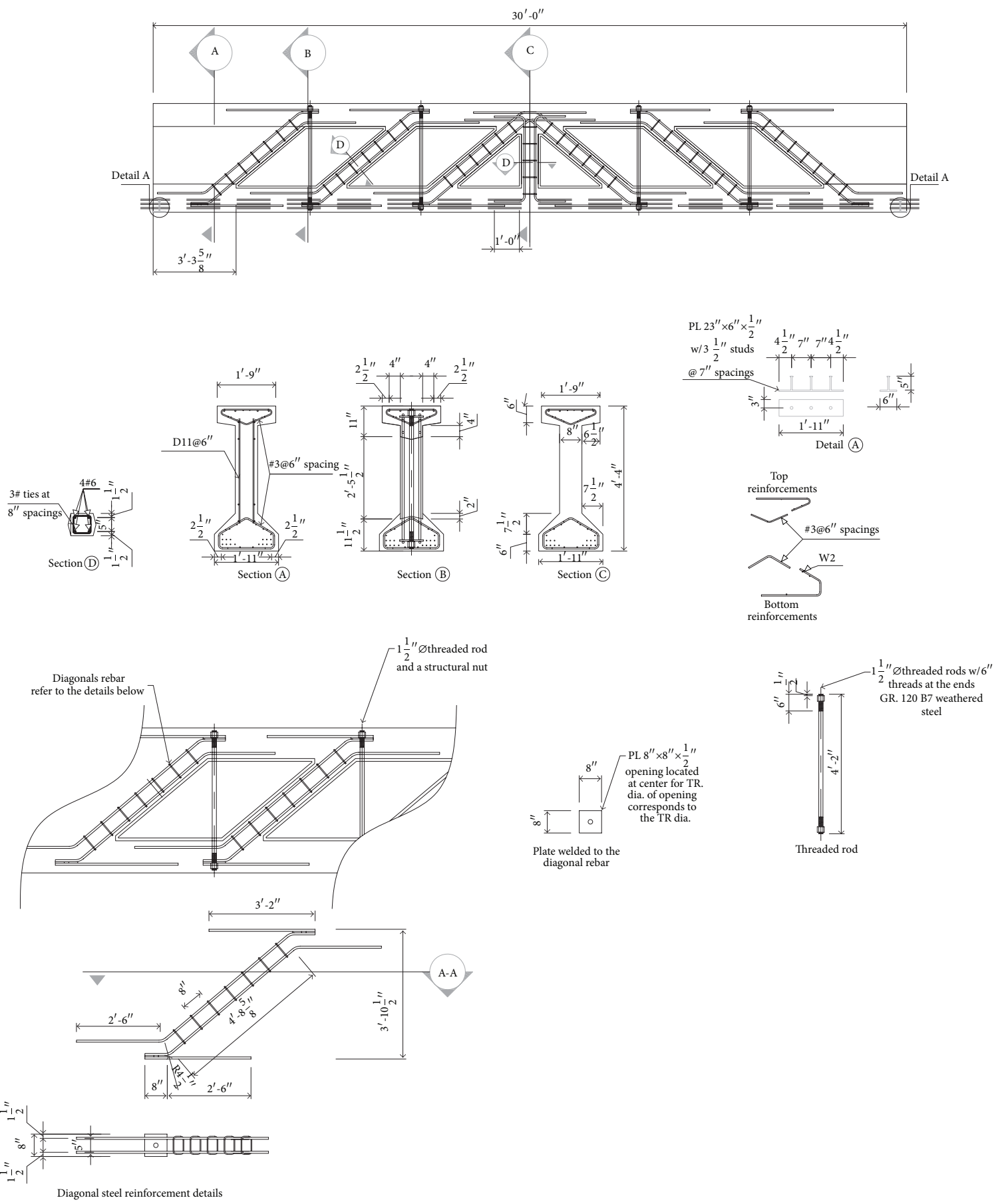

FIGURE 8: Elevation and cross-sections of the specimen $(1 \mathrm{ft}=0.302 \mathrm{~m} ; 1 \mathrm{in} .=25.4 \mathrm{~mm})$.

The top flange had 2 number 25 (\#8) bars tied using number 10 (\#3) stirrups at $150 \mathrm{~mm}$ (6 in.) spacing. After the form was closed, the top flange reinforcement assembly was placed and lumber yokes were used to tie the forms from the top.

The specimen was cast on March 11, 2013 using specified $55 \mathrm{MPa}(8,000 \mathrm{psi})$ self-consolidating concrete. The mixture was designed using type I/II Portland cement with $30 \%$ replacement of class $\mathrm{C}$ fly ash and a mixture of $10 \mathrm{~mm}$ (3/8 in.) crushed limestone and natural sand and gravel.
The SCC had an average spread of $800 \mathrm{~mm}$ (28 in.), $T_{50}$ less than $2 \mathrm{sec}$., J-ring spread reduction less than $50 \mathrm{~mm}$ ( 2 in.), and visual stability index (VSI) of 1.0. Nine $100 \mathrm{~mm} \times$ $200 \mathrm{~mm}$ ( 4 in. $\times 8$ in.) cylinders were taken to evaluate the compressive strength at release, testing, and 28 days. Casting SCC started at the middle of the specimen. Two pipe cameras were attached at the bottom of the truss, one at each end to record the concrete flow around the reinforcement and strands. Another camera was recording the casting process 


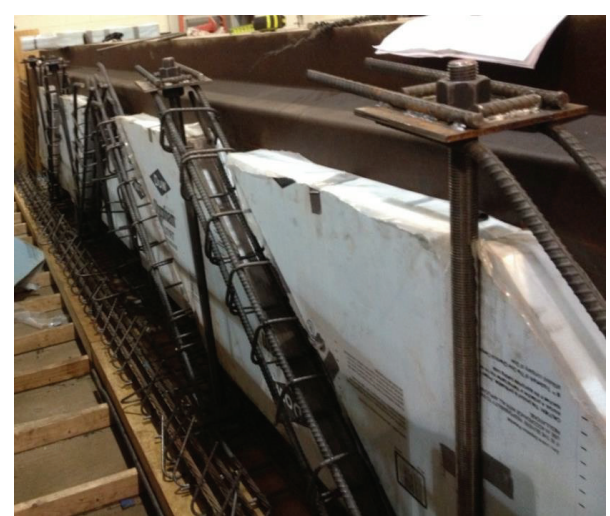

Figure 9: All reinforcements after being installed in the form.

from the top. The high flowability and passing ability of SCC made it easy to fill the bottom flange with no consolidation problems. However, as soon as SCC started to fill truss diagonals and verticals, two foam panels started to float as the buoyant forces broke the bond between the steel forms and foam block-outs. Several actions were taken to keep the foam block-outs in place against the uplifting force. Lumber pieces were used as spacers between the foam and top flange reinforcement and between the top reinforcement and the steel form to prevent further movements of the block-outs. This experiment indicated that foam panels were not a good choice for forming.

After curing the specimen with wet burlap for 3 days, the concrete strength reached $52.4 \mathrm{MPa}$ (7,600 psi), forms were stripped and strands were released on March 14, 2013. Steel forms were easy to strip; however, foam block-outs were embedded in the concrete and did not come out easily. The pressure of the concrete on the foam made it difficult to pull out of the concrete; in addition to having a thin layer of concrete between the foam and the steel form in some locations, which had to be chipped out. Foam block-outs had to be cut into small pieces using an electric saw. Removing the block-outs at the corners was even more challenging. A small chipping hammer was used to carefully remove the remaining foam without damaging the concrete. The movement of the foam block-outs while casting resulted in deviations in the dimensions, angles, and locations of two diagonal members and two vertical members as shown in Figure 10.

Prestressing strands were released using gradual detensioning and specimen ends were inspected for cracking. Few cracks appeared at south and north ends that were mostly horizontal and extended for the full thickness of the web and few inches in the longitudinal direction. These cracks are due to the bursting force of prestressing and were not controlled properly because the end zone reinforcements were not placed as close as they should be to the bulkheads. Few shrinkage cracks occurred in the top flange at the locations were the lumber pieces were placed to prevent the floating of the foam. These cracks were not critical for the proposed testing as they occurred only in the top flange, which is a compression member.
3.4. Specimen Testing. Two roller supports were placed on concrete blocks and spaced $8.9 \mathrm{~m}(29.5 \mathrm{ft})$ apart on center to support the $9 \mathrm{~m}(30 \mathrm{ft})$ long truss specimen. The rollers were centered on the $150 \mathrm{~mm}$ ( $6 \mathrm{in}$.) wide bearing plates embedded in the truss at both ends. A steel frame with a $1,780 \mathrm{kN}$ (400 kip) loading jack was placed as shown in Figure 11 to load the specimen at midspan section.

To clearly see and track crack propagation of truss elements during loading, one side of the specimen was painted in white, while strain gages were attached to the other side. Linear variable differential transforms (LVDTs) were used to monitor the slippage of strands during testing. A deflection gage was installed to measure midspan deflections during loading. The specimen was tested on March 29, 2013. Concrete cylinders were tested and the compressive strength was found to be $72.4 \mathrm{MPa}(10,500 \mathrm{psi})$ at that time. During loading, the specimen was visually inspected at $222.5 \mathrm{kN}$ (50 kip) load increments and cracking was being marked up. At $222.5 \mathrm{kN}$ (50 kip), the deflection reached $5 \mathrm{~mm}$ (0.19 in.) with no visible cracking. The loading continued to $445 \mathrm{kN}$ (100 kip) and deflection reached $10 \mathrm{~mm}$ (0.39 in). Minor horizontal cracks were observed at the corners between diagonals and top/bottom flanges as shown in Figure 12.

At $667 \mathrm{kN}$ (150 kip), the deflection reached $15 \mathrm{~mm}$ (0.57 in.) and cracking continued at acute-angled corners between the solid web and bottom flange. The middle vertical started to crack as well at the top and bottom. At $890 \mathrm{kN}$ (200 kip), deflection reached $20 \mathrm{~mm}$ (0.75 in.) and cracking occurred at all the acute-angled corners. At 1,112 kN (250 kip), deflection reached $24 \mathrm{~mm}$ (0.93 in.) and cracking severity had not significantly increased except at the web/bottom flange corner. After $1,112 \mathrm{kN}$ (250 kip), the load increased continuously without interruptions up to failure at $1,712 \mathrm{kN}$ (385 kip). Excessive cracking was observed at the bottom flange around its connection to vertical rods and diagonals as shown in Figure 13. The failure was dramatic as the onethreaded rod was pulled out of the bottom flange causing the adjacent diagonal to snap as shown in Figure 14. This failure occurred as one of the \#6 anchor bars welded to the washer plate was completely sheared as shown in Figure 15. Despite the high load carrying capacity that the specimen achieved, it is believed that having longer anchor bars and hat bars for bottom flange confinement around the anchor bars would have postponed or even eliminated this mode of failure. Also, chamfering sharp edges and using curved corners would have reduced stress concentrations and minimized premature cracking at these locations.

3.5. Analysis of Results. Figure 16 plots the load-deflection relationship of the truss specimen. This plot indicates that the specimen had a linear elastic behavior up to the cracking load, which is determined to be $1,580 \mathrm{kN}$ (355 kip) using the tangents method. This load is $7 \%$ higher than the $1,468 \mathrm{kN}$ (330 kip) predicted cracking load. The measured deflection at the cracking load was found to be $34 \mathrm{~mm}$ (1.33 in.), which is $33 \%$ higher than the $25 \mathrm{~mm}$ (1.0 in.) predicted deflection. This is primarily due to the premature cracking that was observed at almost all acute-angled corners, which might have resulted in stiffness reduction. Also, the deviations between specified 


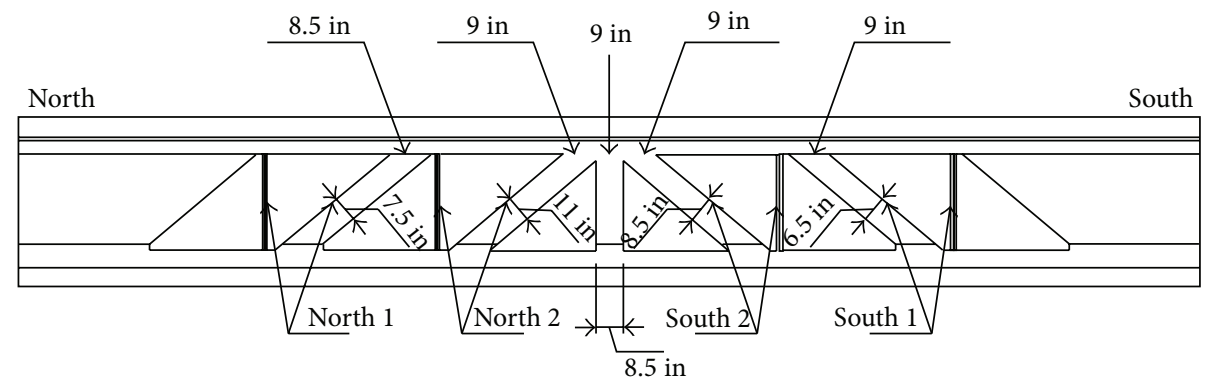

FIgURE 10: Actual truss member concrete dimensions after casting $(1 \mathrm{in} .=25.4 \mathrm{~mm})$.

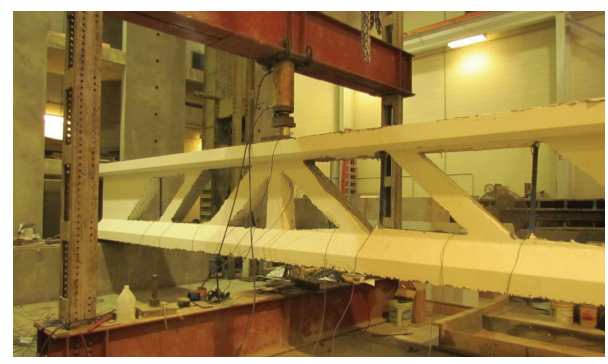

FIGURE 11: Truss specimen before testing.

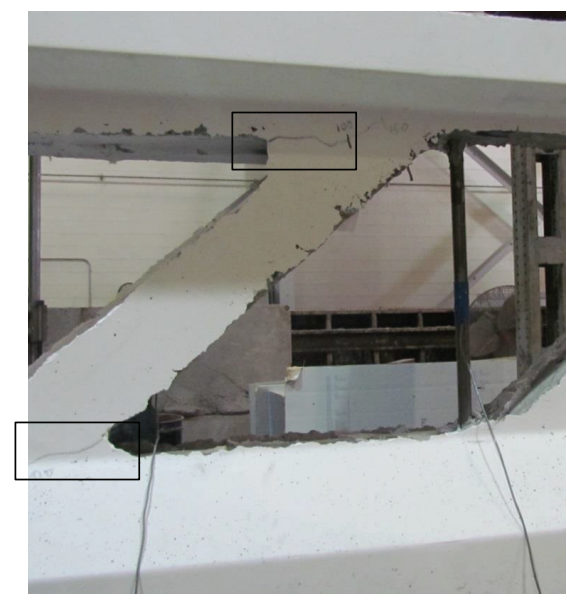

Figure 12: First cracks observed at $445 \mathrm{kN}$ (100 kip).

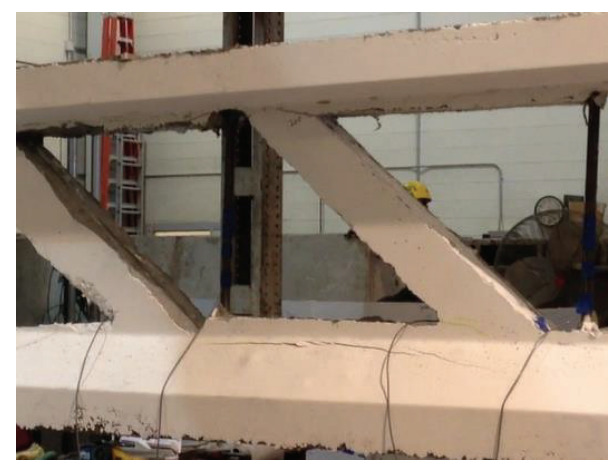

FIGURE 13: Excessive cracking at the bottom flange before failure.

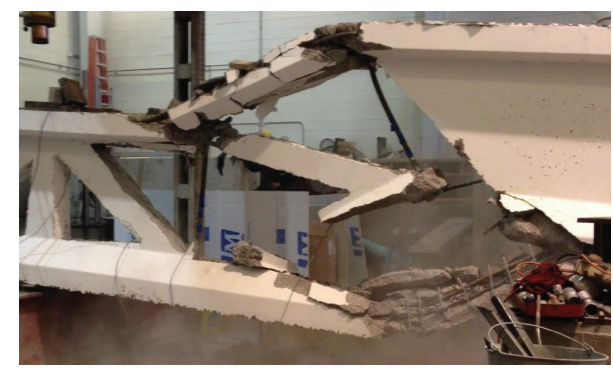

FIGURE 14: Failure of the truss specimen.

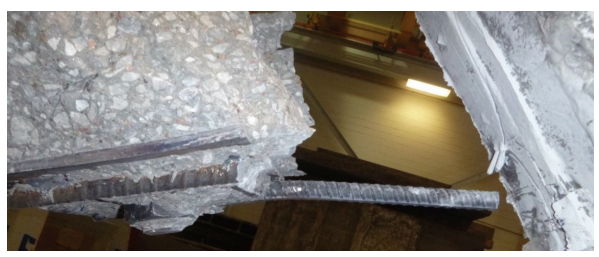

FIGURE 15: Shearing of anchor bars at the failure location.

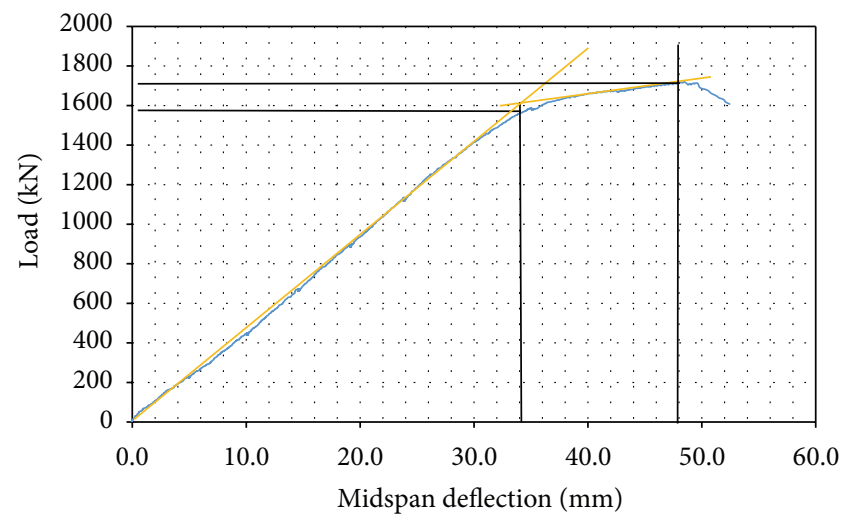

FIGURE 16: Load versus deflection curve (black lines indicate end of elastic behavior).

and actual dimensions could have influenced the behavior of the specimen. Figure 16 also indicates that the ultimate load was $1,713 \mathrm{kN}$ (385 kip), which is $3.8 \%$ lower than the predicted capacity of $1,779 \mathrm{kN}$ (400 kip) due to the premature pullout of 
the vertical threaded rod as a result of inadequate anchorage in the bottom flange.

Figure 17 shows the measured slippage of $17.8 \mathrm{~mm}$ ( $0.7 \mathrm{in}$.) diameter prestressing strands during loading. This plot indicates that all the recorded readings are significantly less than $0.25 \mathrm{~mm}$ (0.01 in.), which is the limit for initial slippage. The highest recorded value was even less than $0.025 \mathrm{~mm}$ (0.001 in.), which is the measurement accuracy of the used LVDTs, indicating no slippage up to failure load. This means that $17.8 \mathrm{~mm}(0.7 \mathrm{in}$.) diameter prestressing strands were fully developed within the $4.5 \mathrm{~m}(15 \mathrm{ft})$ distance (i.e., half of the specimen length), which is the predicted development length using ACI 318-11. It should be noted that the high value recorded by the south LVDT at the failure load is incorrect due to the sudden movement of the specimen at the moment of failure.

Figure 18 plots the measured strain in four vertical members of the truss specimen versus the applied load. These verticals are $38 \mathrm{~mm}$ ( $1.5 \mathrm{in}$.) diameter threaded rods that have a yield strength of $724 \mathrm{MPa}(105 \mathrm{ksi})$ and ultimate strength of $862 \mathrm{MPa}(125 \mathrm{ksi})$. The maximum measured strain reached $2.6 \%$ (at the south rod \#1 where the failure occurred). Also all measured strains in the four threaded rods had significantly exceeded the yield strain of $0.36 \%$. Figure 19 plots the forces in the four threaded rods versus the applied load. This plot indicates that the forces in all the four threaded rods reached the yield force of $689 \mathrm{kN}$ ( $155 \mathrm{kip}$ ), which is $14 \%$ more than the predicted design force of $605 \mathrm{kN}$ (136 kip).

Figure 20 plots the measured strains in the four reinforced concrete diagonal members of the truss specimen versus the applied load. This plot indicates that the measured strains varied significantly among the four diagonal members due to the variation in their angles and concrete dimensions (e.g., the width of the south diagonal \#1 was $165 \mathrm{~mm}$ (6.5 in.), while the width of the north diagonal \#2 was $280 \mathrm{~mm}$ (11 in.)). However, they were all much lower than the ultimate design strain of concrete $(0.3 \%)$. The maximum ultimate strain reached $0.1 \%$ at the south diagonal $\# 1$, where failure happened, and the minimum ultimate strain reached $0.045 \%$ at the north diagonal $\# 2$. Also, the straight line relationships in all diagonal members indicate their linear elastic behavior up to failure load. Therefore, the truss failure due to crushing of the diagonals is a low probability mode of failure. Figure 21 plots the forces in all four diagonal members versus the applied load. This plot indicates that the ultimate compressive force varied from $1,179 \mathrm{kN}$ (265 kip) at the north diagonal $\# 2$ to $1,446 \mathrm{kN}$ (325 kip) at the south diagonal \#1, where failure occurred. The forces in all diagonal members, except the north diagonal $\# 2$, exceeded the design force of $1,192 \mathrm{kN}$ (268 kip), which indicates that the design of the diagonals was adequate.

\section{Conclusions and Recommendations}

This research aimed to develop a precast concrete truss system for roof applications that is lightweight and aesthetically pleasing, can span up to $48 \mathrm{~m}$ (160 ft), and can be fabricated

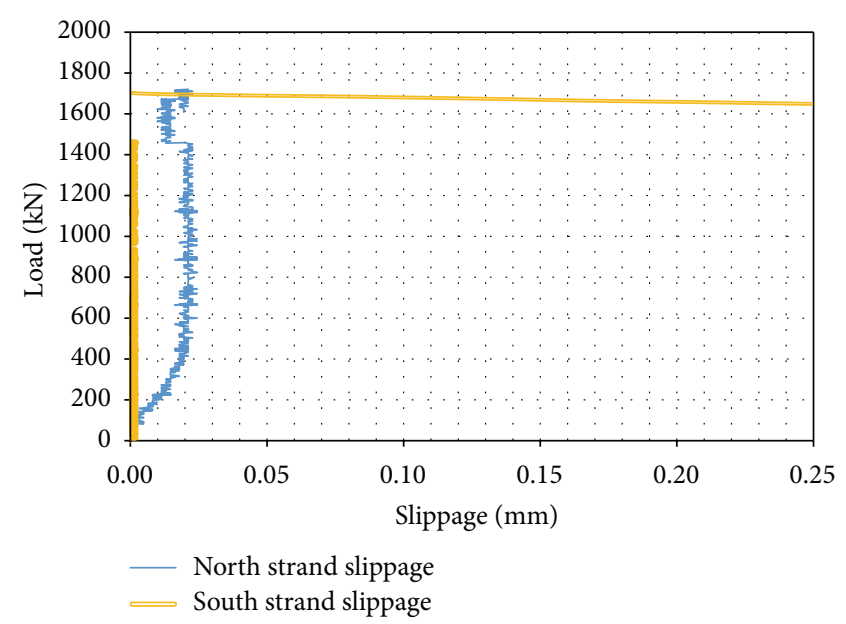

FIGURE 17: Strand slippage measurements $(1 \mathrm{kip}=4.45 \mathrm{kN}, 1$ in. $=$ $25.4 \mathrm{~mm}$ ).

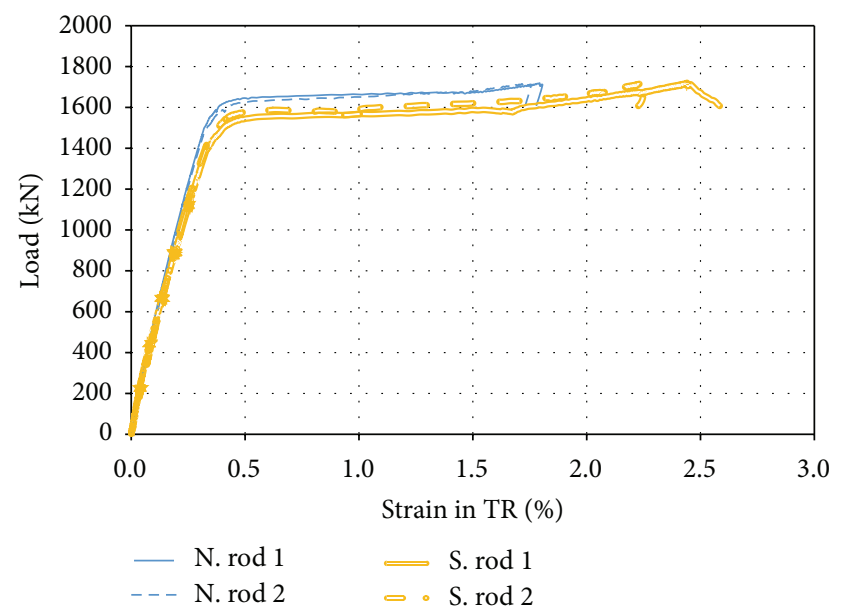

FIGURE 18: Tensile strains in the four threaded rods (1 kip = $4.45 \mathrm{kN})$.

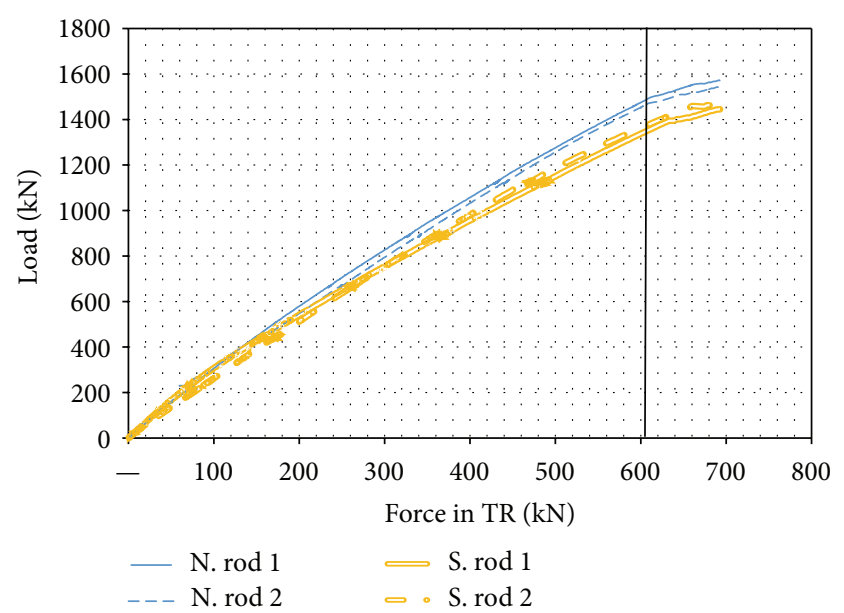

FIGURE 19: Tension forces in the four threaded rods (black line indicates yield force; $1 \mathrm{kip}=4.45 \mathrm{kN}$ ). 


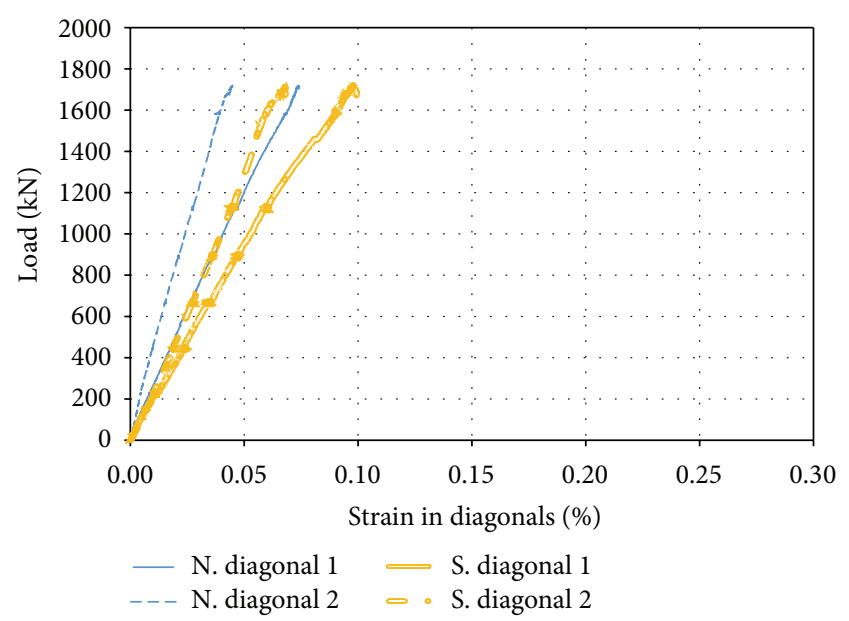

Figure 20: Compressive strains in the diagonal members (1 kip = $4.45 \mathrm{kN})$.

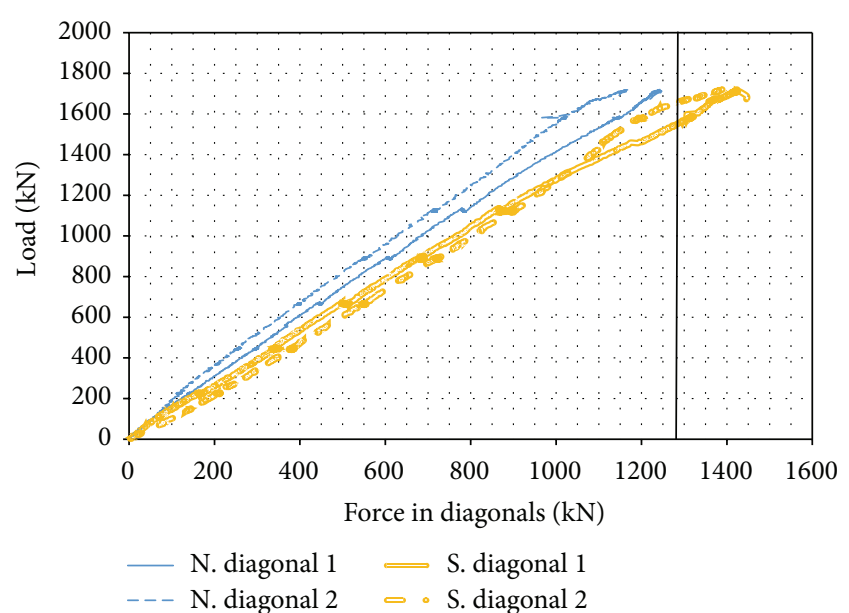

FIgURE 21: Compressive forces in the diagonal members (black line indicates yield force; $1 \mathrm{kip}=4.45 \mathrm{kN}$ ).

using standard precast practices in the USA. Based on the presented work, three main conclusions can be made.

(1) Fabrication of the proposed truss system is practical and efficient. The proposed method of fabrication was evaluated experimentally by producing a $9 \mathrm{~m}$ $(30 \mathrm{ft})$ long truss specimen using economical and commercially available components: standard bridge girder form, foam block-outs, vertical threaded rods, and conventional reinforcement. The success of the proposed method is also attributed to the use of high strength self-consolidating concrete (SCC) that fills the complex form, encapsulates the reinforcement, and provides a smooth finished surface without any mechanical consolidation.

(2) Structural testing of the truss specimen that was designed and detailed to resist the forces generated in an example building indicated the adequacy of the proposed design method and connection details.
Few recommendations were made, as shown below, to further improve the performance of the proposed system.

(3) The 2D frame models and 3D finite element models can be used to accurately predict the behavior of the proposed system. Forces obtained from these models can be used to design truss members using the strutand-tie method and in accordance to the existing building code. FEA can be used to accurately predict stress concentration at truss member connections.

Based on the analytical and experimental investigations, several recommendations could be made to improve the proposed truss system.

(1) Use chamfered edges and curved corners instead of the sharp ones to avoid stress concentrations and add nominal reinforcement to control cracking at these locations.

(2) Use adequate top flange and bottom flange conferment reinforcement to help anchoring diagonal and vertical reinforcement, which must be fully developed to prevent pullout.

(3) Avoid using foam block-outs due to the difficulty of gluing them to the form and stripping them. Using light gage steel pans or fiber glass panes is highly recommended for efficient and economical fabrication as they can have multiple reuses.

(4) Diagonal bars should be tied together after being placed in the forms to accommodate the tolerances especially when bar lengths and bent diameters are not exact. This practice will allow the diagonals to slide against each other. Another suggestion for fabrication is to assemble all the reinforcements in a stiff manner outside the form to precisely match the form dimensions. Then, the assembly is tied together, lifted by a crane, and placed in the form in one step.

(5) Self-consolidating concrete with high flowability (average spread of $800 \mathrm{~mm}(28 \mathrm{in}$.) $\pm 50 \mathrm{~mm}(2 \mathrm{in}$.$) ),$ passing ability (nominal maximum size aggregate is $10 \mathrm{~mm}$ (3/8 in.)), resistance to segregation (VSI not more than 1.0), and low viscosity $\left(T_{50}<2 \mathrm{sec}\right.$.) is required to simplify production and ensure proper filling of the complex truss form without mechanical consolidation.

\section{Conflict of Interests}

The authors declare that there is no conflict of interests regarding the publication of this paper.

\section{Acknowledgments}

The technical support of the Precast/Prestressed Concrete Institute (PCI) advisory committee members is acknowledged; and the financial support of the PCI Daniel P. Jenny Fellowship is appreciated. Assistance was provided by 
Musa Alawneh as a scholarship partner. Support was also given by University of Nebraska-Lincoln (UNL) graduates students and staff: Kelvin Lein, Afshin Hatami, Shaddi Assad, Mohamed El-Kady, and Micheal Asaad.

\section{References}

[1] PCI, PCI Design Hnadbook, Precast/Prestressed Concrete Institute (PCI), Chicago, Ill, USA, 2010.

[2] PCI, "The 50 most significant precast concrete projects," ASCENT Magazine, 2004.

[3] P. H. Shah and H. R. May, "Precast vierendeel trusses provide unique structural facade for parking structure," Precast/Prestressed Concrete Institute, Journal, vol. 22, no. 4, pp. 2439, 1977.

[4] W. T. Carroll, F. W. Beaufait, and R. H. Bryan, "Prestressed concrete trusses," ACI Journal, vol. 75, no. 8, pp. 367-373, 1978.

[5] M. DeSutter, United States of America Patent 7,275,348 B2, 2007.

[6] A. Trygestad and M. DeSutter, "Bookmen stacks, cobalt condos use ER-POST for column-free space," PCI Journal, vol. 52, no. 3, pp. 58-71, 2007.

[7] ASCE/SEI 7, Minimum Design Loads for Buildings and Other Structures, American Society of Civil Engineers (ASCE), Reston, Va, USA, 2010.

[8] ACI 318, Building Code Requirments for Structural Concrete (ACI 318-11) and Commentary, American Concrete Institute (ACI), Farmington Hills, Mich, USA, 2011.

[9] ASTM A193, "Standard specification for alloy-steel and stainless steel bolting for high temperature or high pressure service and other special purpose applications," ASTM Standard A193M-14, ASTM International, West Conshohocken, Pa, USA, 2014.

[10] AISC, Steel Construction Manual, American Institute of Steel Construction (AISC), Chicago, Ill, USA, 14th edition, 2012. 

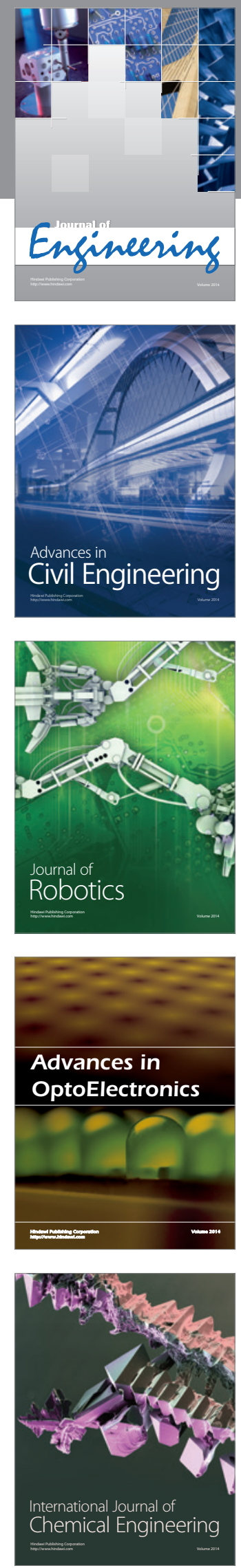

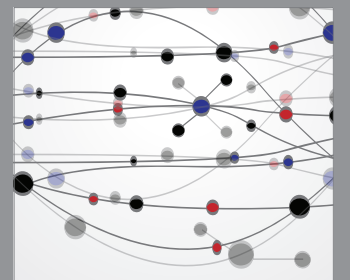

The Scientific World Journal
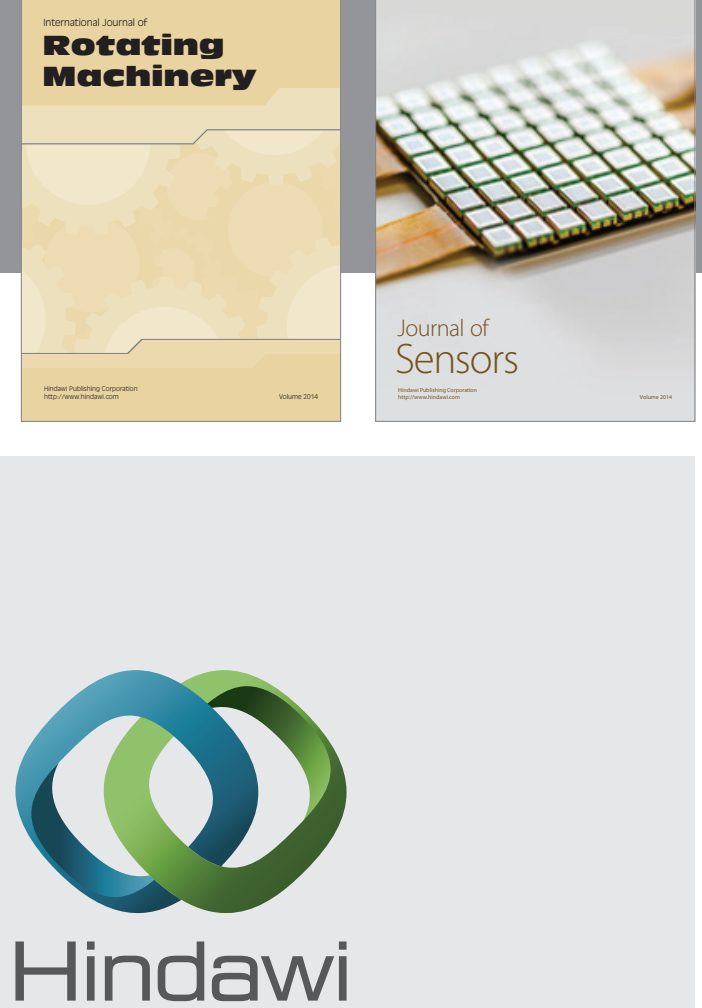

Submit your manuscripts at http://www.hindawi.com
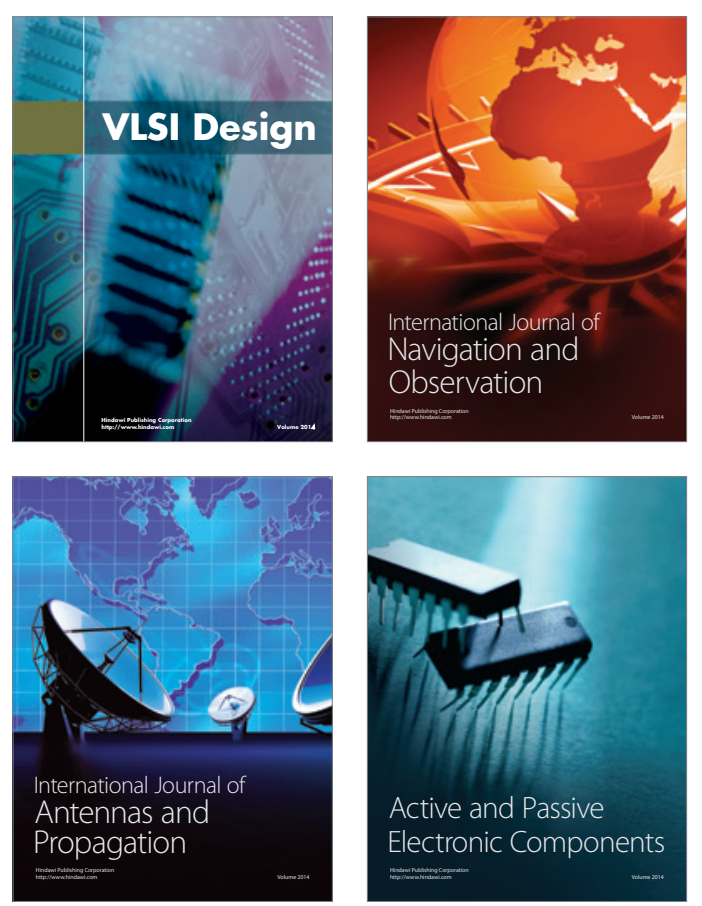
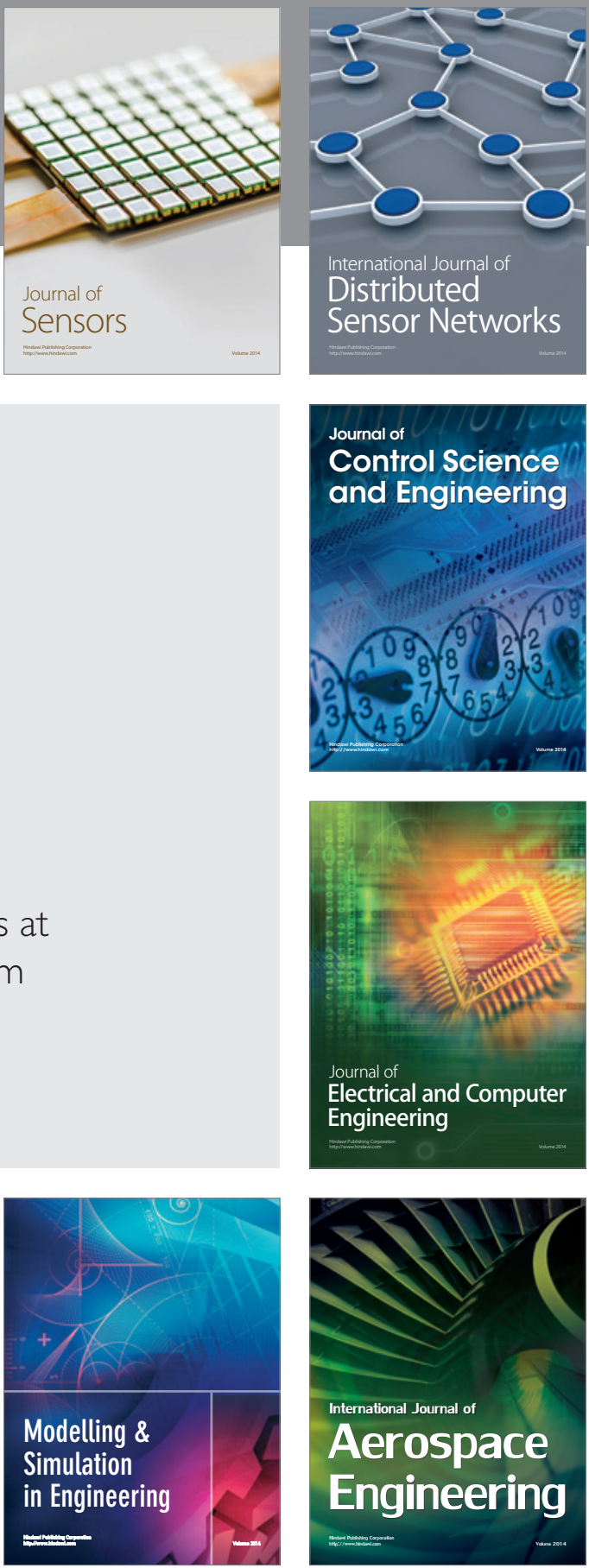

Journal of

Control Science

and Engineering
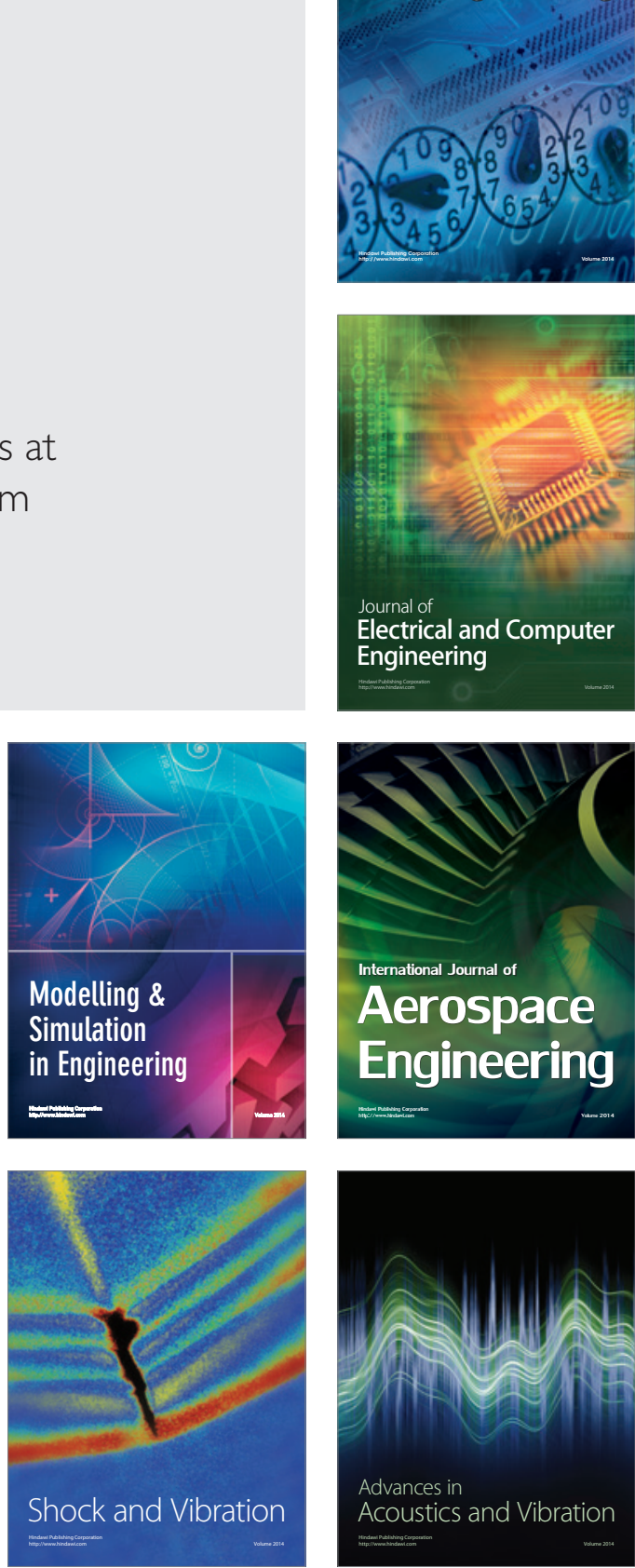